\title{
Expression of a novel mRNA in human head and neck squamous cell carcinoma cells
}

\author{
J A Werner, T Görögh, B M Lippert, S Gottschlich, K Heidorn, B J Folz, H Rudert
}

\begin{abstract}
Aims-The differential display reverse transcription polymerase chain reaction (DDRT-PCR) technique was used to search for differences between the mRNA expression profiles of squamous cell carcinoma (SCC) cell lines established from head and neck tumours and normal keratinocytes from the mucosa of the upper aerodigestive tract.

Methods-Total RNA prepared from both cell types was reverse transcribed into cDNA then amplified in a PCR mixture. To compare the electrophoretic patterns, mRNAs were amplified by nested PCR using specific oligonucleotides. Additionally, using labelled cDNA probes, northern hybridisation was carried out on three cancer cell lines of different origin, a biopsy from a parotid gland pleomorphic adenoma, healthy mucosa, and keratinocytes.
\end{abstract}

Results-Comparison of the separated bands revealed a fragment with a differential expression pattern in the SCC cells. This cloned sequence of a 336 base pair mRNA fragment exhibited no significant homology with known transcripts. Additionally, after amplification and sequencing of the $3^{\prime}$ end of the fragment no homology with a known human gene sequence was found. However, low homology with a genomic sequence of a nematode was found. Northern hybridisation confirmed the selective expression of this fragment in SCC cells versus the cancer cell lines of different origin, the biopsy of the pleomorphic adenoma, keratinocytes, and healthy mucosa.

Conclusions-This is the first differentially expressed human genome transcript of squamous cell carcinoma of the head and neck identified by DDRT-PCR. It may prove useful, in the future, to characterise this tumour type.

(F Clin Pathol: Mol Pathol 1997;50:82-86)

Keywords: squamous cell carcinoma; mRNA expression; differential display reverse transcription polymerase chain reaction

The understanding of malignant diseases has grown in recent years, particularly as a consequence of extensive analysis of gene expression. A number of genes affecting nuclear and cytoplasmic functions have been shown to play an important role in the malignant transformation of cells. ${ }^{1-7}$ Various hybridisation procedures are used for the iden- tification of transcripts present in one sample but not in another. ${ }^{8-10}$ However, these methods are difficult to set up, non-reproducible, and they require large amounts of RNA. ${ }^{11}$ In 1992 Liang and Pardee, ${ }^{12}$ as well as Welsh et al, ${ }^{13}$ developed a technique called differential display, or RNA based arbitrarily primed PCR, to improve and accelerate the identification of differentially expressed genes. For mRNA containing a poly(A) sequence at the $3^{\prime}$ end, oligo(dT) nucleotides were used to prime cDNA synthesis. This method was subsequently refined by introducing non-denaturing gels and establishing the appropriate numbers of optimal PCR primers. This improved technique was named differential display reverse transcription polymerase chain reaction (DDRT-PCR). ${ }^{14}$ Using this technique, selectively expressed RNA transcripts have been identified in various organisms ${ }^{15-17}$ and in different human tumours. ${ }^{18}{ }^{19}$ Because the identified fragments can be used for detection and isolation of complete mRNA and cDNA, this method has become an increasingly used, alternative means for rapid analysis of the selective expression of genes involved in the pathogenesis of various diseases.

Applying the DDRT-PCR technique, we studied squamous cell carcinoma (SCC) cells of the larynx and the floor of the mouth, as well as corresponding normal keratinocytes, to identify and characterise their differential expression of mRNA. We also used specific probes to identify complementary RNA fragments expressed in SCC cells and tumour biopsies.

\section{Methods}

CARCINOMA CELLS AND TUMOUR BIOPSIES

Human head and neck SCC cell lines were studied. Two of the cell lines, UM-SCC-17A and $14 \mathrm{~B}$, had been established and characterised by Carey et $a l,{ }^{20}$ the cell line, Hlac-78, by Zenner et $a l^{21}$ the cell line, HCFMK-1, by Görögh et $a l^{22}$ and normal keratinocytes by Saffran et al..$^{23}$ The SCC cell lines were grown in minimum essential medium with Earle's salts and L-glutamine, without addition of non-essential amino acids or sodium bicarbonate, but in the presence of $20 \mathrm{mM}$ Hepes buffer and $10 \%$ (vol/vol) fetal calf serum (Biochrome, Berlin, Germany) at $37^{\circ} \mathrm{C}$ in a $5 \%$ $\mathrm{CO}_{2}$ humidified atmosphere. The keratinocyte cultures were grown in serum free medium (Gibco, Eggenstein, Germany) supplemented with $50 \mathrm{mg} / \mathrm{ml}$ bovine pituitary extract and $1.5 \mathrm{ng} / \mathrm{ml}$ epidermal growth factor in the presence of $100 \mathrm{U} / \mathrm{ml}$ penicillin/streptomycin. Bacterial contamination of the cultures was 
screened by DNA staining as described by Russell $e t a l^{4}$ and by inoculation of the culture medium at $37^{\circ} \mathrm{C}$ with and without cells.

Two carcinoma biopsies, five normal upper aerodigestive tract mucosa samples, one biopsy of a parotid gland pleomorphic adenoma, RNA from an adenocarcinoma cell line of the lung (HTB-179), the malignant melanoma cell line (HTB-66), and the breast carcinoma cell line (HTB-20) (ATCC, Rockville, USA) were used for northern blotting. The cell lines were grown under the conditions described above. One of the two tumour biopsies subjected to hybridisation was a moderately differentiated SCC of the glottis, the other was a poorly keratinised SCC from the pyriform fossa.

\section{ISOLATION OF TOTAL RNA}

For rapid and reproducible preparation of total RNA, the Rneasy Kit (Qiagen, Hilden, Germany) was used in accordance with the manufacturer's instructions. After determination of the RNA content using a photometer (Uvicon931 UV; Kontron, Hamburg, Germany), samples of total RNA were adjusted to $3.5 \mu \mathrm{g}$ for subsequent first-strand cDNA synthesis. Quantitative analysis of the mRNA content was carried out using RT-PCR of actin as a control.

\section{FIRST-STRAND CDNA SYNTHESIS}

Total RNA $(3.5 \mu \mathrm{g})$ was heat denatured $\left(65^{\circ} \mathrm{C}\right.$, 10 minutes), chilled on ice and subjected to oligo(T) primed reverse transcription using a first-strand cDNA synthesis kit (Pharmacia, Freiburg, Germany). Reverse transcription in a final volume of $33 \mu \mathrm{l}$ was performed at $37^{\circ} \mathrm{C}$ for 60 minutes in the presence of $0.2 \mu \mathrm{M}$ of one of 12 different dodecameric anchored oligo(T) primers ( $\mathrm{dT}_{10} \mathrm{MN} ; \mathrm{A}, \mathrm{G}$ or $\mathrm{C}$ ) and 40 units of RNAse inhibitor (RNAsin; Gibco). Following synthesis of the completed first-strand cDNA, the resulting double-stranded RNA:cDNA heteroduplex was heat denatured at $95^{\circ} \mathrm{C}$ for five minutes to provide $\mathrm{CDNA}$ as a template for polymerisation.

\section{MRNA DIFFERENTIAL DISPLAY}

The first-strand cDNA product $(160 \mu \mathrm{g})$ was incubated with $0.2 \mathrm{mM}$ of one of 26 decameric arbitrary primers, ${ }^{14} 0.2 \mu \mathrm{M}$ of the corresponding anchored oligo(T) primer, $2.5 \mu \mathrm{M} \mathrm{dNTPs,}$ $1.5 \mathrm{mM} \mathrm{MgCl}_{2}$, and $2.5 \mathrm{U}$ Taq polymerase in a total volume of $50 \mu \mathrm{l}$. Low-stringency PCR was run for 40 cycles at $95^{\circ} \mathrm{C}$ for 60 seconds, $40^{\circ} \mathrm{C}$ for 120 seconds, $72^{\circ} \mathrm{C}$ for 30 seconds, with a final extension step at $72^{\circ} \mathrm{C}$ for 10 minutes (Thermocycler 4800; Applied Biosystems, Weiterstadt, Germany). After thermocycling, the amplicons were purified using Qiaquick spin (Qiagen), dried in a vacuum centrifuge, resuspended in $7.0 \mu \mathrm{TE}$ buffer $^{25}$ and run on a $6 \%$ non-denaturing polyarcylamide (PAA) sequencing gel in Mops buffer ${ }^{25}$ at $400 \mathrm{~V}$ for three hours under constant cooling at $15^{\circ} \mathrm{C}$ using a flatbed electrophoresis system (EFB300; Pharmacia). Gels were stained with silver nitrate according to the method of Bassam et $a .^{26}$
ISOLATION, REAMPLIFICATION, AND SEQUENCING OF DIFFERENTIAL DISPLAY

Bands of interest were excised from the gel and the DNA extracted using the Nucleon Easyclean kit (Scotlab, Wiesloch, Germany). Four microlitres of the DNA elution volume of $50 \mu \mathrm{l}$ 으 was subjected to PCR under the same conditions as above, except that the concentra- $\frac{0}{5}$ tion of both primers was reduced to 40 pmol. Routinely, $5 \mu \mathrm{l}$ of the $50 \mu \mathrm{l}$ reamplified products was separated and stained as above. Puri- $\bar{O}$ fied double-stranded DNA fragments were 흠 ligated into the pGEM-T-cloning vector

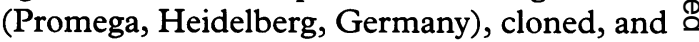
sequenced on a DNA sequencing apparatus (Abi Prism 310; Applied Biosystems).

ANALYTICAL HIGH STRINGENCY NESTED PCR After sequencing of the differentially expressed fragment, $5 \mu \mathrm{l}$ of the first-strand cDNA mixture was subjected to PCR $(50 \mu \mathrm{l})$ using $2.5 \mathrm{U}$ or Taq polymerase, $50 \mu \mathrm{l}$ PCR buffer (Gibco), N $0.2 \mathrm{mM}$ each $\mathrm{dNTP}, 1.5 \mathrm{mM} \mathrm{MgCl}_{2}$, and $\mathrm{N}$ $0.2 \mu \mathrm{mol}$ of forward and reverse primers. The 을 following primers were used: sense 1, 5'-ATG AAG ATA AAG CAC-3'; antisense 1, 5'-TG 음 GGG GAG GGG GTG-3'; sense 2, 5'-TTG TTG GCC ACC-3'; antisense 2, 5'-GCT $\vec{\vartheta}$ TTT TTA CAT-3'. The first PCR was run for .' 30 cycles with sense 1 and antisense 1 primers and the second for 20 cycles with sense 2 and antisense 2 primers at $94^{\circ} \mathrm{C}$ for 60 seconds, $58^{\circ} \mathrm{C}$ for 60 seconds, and $72^{\circ} \mathrm{C}$ for $120 \stackrel{\circ}{\circ}$ seconds, with a five minute extension at $72^{\circ} \mathrm{C}$. $\stackrel{\perp}{\circ}$ After thermocycling, the amplicons were puri- $\overline{\overline{0}}$ fied using Qiaqick spin (Qiagen) and $2 \mu \mathrm{l}$ aliquots of the PCR product were analysed by electrophoresis on a $6 \%$ PAA sequencing gel stained with silver nitrate as above.

ONE-SIDED PCR

One-sided or anchored $\mathrm{PCR}^{27}{ }^{28}$ was carried out to amplify the $3^{\prime}$ end of cDNA. In this procedure, RNA was extracted and transcribed 은 into cDNA using reverse transcriptase (RT) and an oligo(dT) adaptor primer (Gibco). The cDNA was then amplified by PCR $(50 \mu \mathrm{l})$ N using $2.5 \mathrm{U}$ Taq polymerase, $0.2 \mathrm{mM}$ each dNTP, $5 \mu \mathrm{l}$ PCR buffer (Gibco), $0.2 \mu \mathrm{l}$ se- N quence specific primer (SSP) (5'- N CAGGGCTCCTGCCCGATTTG-3') that anneals to a region of the selectively expressed $\stackrel{0}{=}$ fragment obtained by differential display PCR, $\stackrel{\mathcal{D}}{\rightarrow}$ and $0.2 \mu \mathrm{M}$ adaptor primer that targets the poly(A) tail region. The reaction was run for 30 cycles at $94^{\circ} \mathrm{C}$ for 45 seconds, $55^{\circ} \mathrm{C}$ for 30 seconds, and $72^{\circ} \mathrm{C}$ for 90 seconds, with a $10 \stackrel{\mathbb{D}}{\circ}$ minute extension at $72^{\circ} \mathrm{C}$. Purification, electrophoresis, staining and sequence analysis of the PCR product were carried out as described above.

NORTHERN HYBRIDISATION

The 336 base pair cDNA was random prime labelled using the Dig High prime DNA labelling and detection starter kit II (Boehringer Mannheim, Mannheim, Germany). Twenty micrograms of heat denatured, total RNA from all different cell types and biopsies was separated on $0.8 \%$ agarose gels according to 


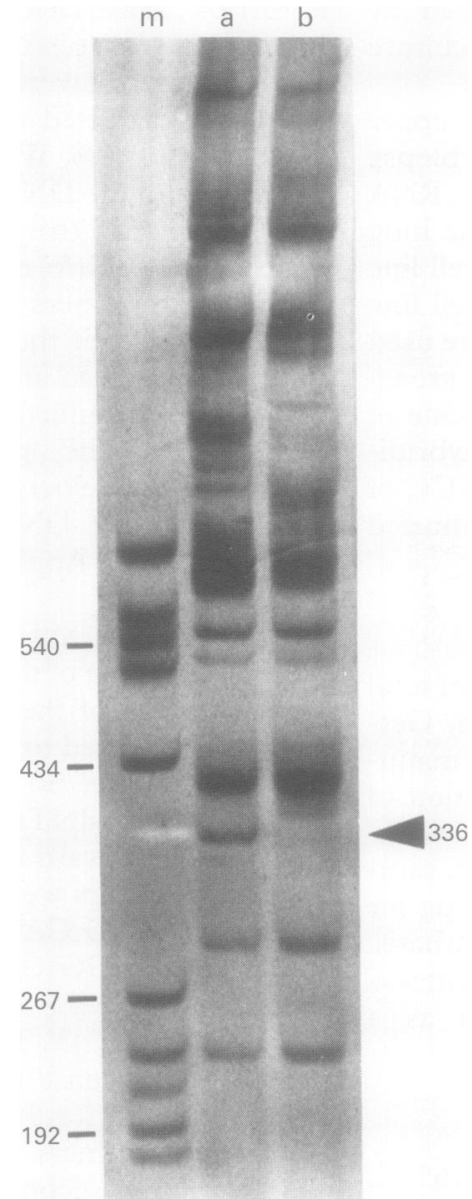

Figure 1 Part of the $m R N A$ expression pattern of laryngeal SCC cells (a) and mucosal keratinocytes (b) using the DDRT-PCR technique. The arrow indicates the differentially expressed 336 base pair band using anchored arbitrary primers. $m$, molecular weight standards.

Table 1 Nucleotide sequence of the 694 base pair fragment obtained from head and neck squamous cell carcinoma cells

\begin{tabular}{|c|c|c|c|c|c|c|c|c|c|c|}
\hline Base pairs & $\mathrm{Nuc}$ & 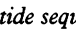 & & & & & & & & \\
\hline $1-30$ & $\underline{\text { TAC }}$ & $\underline{\mathrm{AAC}}$ & GAG & $\underline{\mathrm{GCC}}$ & ATG & AAG & ATA & AAG & CAC & TTC \\
\hline $\begin{array}{l}31-60 \\
61-90 \\
91-120 \\
121-150 \\
151-180 \\
181-210\end{array}$ & $\begin{array}{l}\text { CTT } \\
\text { TCC } \\
\text { GCT } \\
\text { TTC } \\
\text { TTG } \\
\text { TTG }\end{array}$ & $\begin{array}{l}\text { TTG } \\
\text { AGA } \\
\text { CAT } \\
\text { ACA } \\
\text { CTC } \\
\text { GCC }\end{array}$ & $\begin{array}{l}\text { TTG } \\
\text { GTA } \\
\text { TCC } \\
\text { AAG } \\
\text { CAG } \\
\text { TTA }\end{array}$ & $\begin{array}{l}\text { GCC } \\
\text { TCC } \\
\text { CTG } \\
\text { CAA } \\
\text { TCT } \\
\text { GTA }\end{array}$ & $\begin{array}{l}\overline{\text { ACC }} \\
\text { AAC } \\
\text { AAC } \\
\text { CCC } \\
\text { CCA } \\
\text { TTC }\end{array}$ & $\begin{array}{l}\text { TGC } \\
\text { CTT } \\
\text { AAC } \\
\text { TCT } \\
\text { ACA } \\
\text { ATT }\end{array}$ & $\begin{array}{l}\text { ATA } \\
\text { CAA } \\
\text { GGT } \\
\text { GCA } \\
\text { GAA } \\
\text { CAG } \\
\end{array}$ & $\begin{array}{l}\text { TCC } \\
\text { AGC } \\
\text { GCC } \\
\text { CAC } \\
\text { TTT } \\
\text { GGC }\end{array}$ & $\begin{array}{l}\text { AAG } \\
\text { GCT } \\
\text { AGG } \\
\text { CAC } \\
\text { TAC } \\
\text { TCC } \\
\end{array}$ & $\begin{array}{l}\text { GAC } \\
\text { GTG } \\
\text { TAC } \\
\text { AGT } \\
\text { CTC } \\
\text { TGC } \\
\end{array}$ \\
\hline $211-240$ & $\mathrm{CCG}$ & ATT & $\underline{\underline{\mathrm{TG}}} A$ & $A T T$ & $A C T$ & $T T G$ & $\overline{\overline{T T G}}$ & $\overline{\overline{G T T}}$ & $\overline{\overline{A A A}}$ & $\overline{\overline{A A A}}$ \\
\hline $241-270$ & $T G G$ & $\underline{\underline{T G A}}$ & $T T T$ & $C T C$ & $\underline{T A A}$ & $T T C$ & $T A T$ & $A A T$ & $T C A$ & $T T T$ \\
\hline $\begin{array}{l}271-300 \\
301-330 \\
331 \\
337-360 \\
361-390 \\
391-420\end{array}$ & $\begin{array}{c}C T G \\
\boldsymbol{A A A} \\
G T T\end{array}$ & $\begin{array}{l}\overline{C T T} \\
A G C \\
G T A\end{array}$ & $\begin{array}{l}T T A \\
T C A \\
\\
A A G \\
G G G \\
G A C\end{array}$ & $\begin{array}{l}G A A \\
C A T \\
T C A\end{array}$ & $\begin{array}{l}G A T \\
T T G \\
A A G\end{array}$ & $\begin{array}{l}G T A \\
T C T \\
T A A \\
\end{array}$ & $\begin{array}{l}C T G \\
C C T \\
G C A\end{array}$ & $\begin{array}{l}A A T \\
G T A \\
C C A\end{array}$ & $\begin{array}{c}\boldsymbol{A T G} \\
\boldsymbol{C A C} \\
\\
T T C \\
T C T \\
T A C\end{array}$ & $\begin{array}{c}\text { TAA } \\
C T C \\
\\
A A G \\
A T C \\
T A T\end{array}$ \\
\hline $\begin{array}{l}421-450 \\
451-480 \\
481-510\end{array}$ & $\begin{array}{l}T T G \\
T T T \\
A G T\end{array}$ & $\begin{array}{l}T T G \\
G C C \\
C A C\end{array}$ & $\begin{array}{l}A T C \\
T C A \\
T A A \\
\end{array}$ & $\begin{array}{l}A T T \\
A G C \\
C T T\end{array}$ & $\begin{array}{l}T C T \\
C A G \\
T C C\end{array}$ & $\begin{array}{l}\overline{C T C} \\
G T A \\
C T T\end{array}$ & $\begin{array}{l}C C A \\
C T A \\
G G G\end{array}$ & $\begin{array}{l}C T T \\
A C T \\
A A C\end{array}$ & $\begin{array}{l}A C C \\
C C A \\
A C T\end{array}$ & $\begin{array}{l}A C A \\
C C T \\
T A A \\
\end{array}$ \\
\hline $511-540$ & $C C T$ & $G G T$ & $T G T$ & $G A G$ & $T A A$ & $A A A$ & $A A G$ & $A A T$ & $G A A$ & $\overline{C A T}$ \\
\hline $541-580$ & $T T G$ & $A G A$ & $T G T$ & $\underline{T G A}$ & $\overline{A A C}$ & $A A C$ & $T A T$ & $C G G$ & GNA & $G A T$ \\
\hline $\begin{array}{l}581-610 \\
611-640\end{array}$ & $\begin{array}{l}G T C \\
T C C\end{array}$ & $\begin{array}{l}A A T \\
A C A\end{array}$ & $\begin{array}{l}G A A \\
G A G\end{array}$ & $\begin{array}{l}\overline{C A G} \\
A A A\end{array}$ & $\begin{array}{l}C T C \\
T G A \\
\end{array}$ & $\begin{array}{l}A A G \\
T G A \\
\end{array}$ & $\begin{array}{l}A C T \\
C T G\end{array}$ & $\begin{array}{l}G G A \\
A A T\end{array}$ & $\begin{array}{l}A T T \\
A G T\end{array}$ & $\begin{array}{l}A A T \\
C A A\end{array}$ \\
\hline $641-670$ & $T T T$ & $A G A$ & $A A T$ & $A A A$ & $\overline{\overline{A A C}}$ & $\overline{\overline{T T G}}$ & $G A C$ & $T T A$ & $A A T$ & $T C C$ \\
\hline $671-700$ & $A A A$ & $A T G$ & $\overline{\overline{A A A}}$ & $\overline{\overline{A A A}}$ & $A A A$ & $A A A$ & $A A A$ & $A A A$ & & \\
\hline
\end{tabular}

The arbitrary 10 base pair primer that was used is underlined. Primers for analytical high stringency nested PCR are highlighted by boldface.

1 sense base pairs 13-27, 1 antisense base pairs 312-325, 2 sense base pairs 34-45, 2 antisense base pairs $294-306$.

The sequence of the 486 base pair product that was generated using the SSP and oligo(dT) primer is indicated by italics. SSP, as well as start and stop codons, are double underlined. the method of Sambrook et al. ${ }^{25}$ After ethidium bromide staining of $28 \mathrm{~S}$ and $18 \mathrm{~S}$ rRNAs, the gels were subjected to capillary transfer on to a positively charged nylon membrane (Boehringer Mannheim) overnight at room temperature. The transferred RNA was subsequently immobilised by UV irradiation, membranes were prehybridised at $50^{\circ} \mathrm{C}$ for one hour, and hybridised at $50^{\circ} \mathrm{C}$ for 14 hours in Easy $\mathrm{Hyb}$ solution (Boehringer Mannheim). Membranes were then washed twice at room temperature for 15 minutes per wash, in $0.3 \mathrm{mM} \mathrm{NaCl}, 30 \mathrm{mM}$ sodium citrate ( $\mathrm{pH} 7.0$ ) containing $0.1 \%$ (wt/vol) sodium dodecyl sulphate (SDS), and washed twice again for 15 minutes per wash in $70 \mu \mathrm{M} \mathrm{NaCl}$, $7.0 \mathrm{mM}$ sodium citrate ( $\mathrm{pH} 7.0)$ containing $0.1 \% \mathrm{SDS}$ at $68^{\circ} \mathrm{C}$. After stringency washes, the membranes were prepared for chemiluminescent detection with disodium 3(4-methoxyspiro \{1,2-dioxetane-3,2'-(5-chloro) tricyclo[3.3.1.1., ${ }^{3,7}$ decan\}-4-yl)phenyl phosphate (Boehringer Mannheim) according to the manufacturer's instructions. Finally, blots were exposed on to $x$ ray film for two to 20 minutes using an intensifier screen.

\section{Results}

DIFFERENTIAL EXPRESSION PATTERN

To show the mRNA expression pattern of the cells to be examined, the reverse transcribed cDNA populations were comparatively analysed by DDRT-PCR. Non-denaturing PAA gel electrophoresis could detect selective expression of a 336 base pair mRNA fragment in the head and neck SCC cell line, unlike normal keratinocytes derived from pharyngeal and laryngeal mucosa (fig 1). The reverse transcription step and the PCR reaction for the lane that exhibited a differentially expressed band were repeated and a reproducible difference was corroborated (data not shown). This differentially expressed cDNA fragment was recovered from the gel, reamplified, and cloned into a plasmid vector.

NUCLEOTIDE SEQUENCE OF THE CDNA FRAGMENT After sequencing of the differentially expressed fragment using both forward and reverse M13 primers, the first 336 bases could be obtained reproducibly. As shown in table 1, the nucleotide sequence begins with a 10 mer forward arbitrary primer and ends with the last 10 bases being palindromic to the complementary sequence of the same primer. Because this sequence represented only a part of the complete mRNA, the polyadenylation signal and the poly(A) tail could not be seen. The sequence was read from the $5^{\prime}$ to the $3^{\prime}$ end in all three possible reading frames and routinely compared with the GenBank database to identify the differentially expressed fragment. In all instances, there was no exact match with any database sequences (including virus, prokaryote, and eukaryote sequences), suggesting the identification of an unknown transcript. However, a sequence region of 54 base pairs showed $63 \%$ homology with the human $\mathrm{T}$ cell receptor $\beta$ locus. This was the highest homology reached for this 336 base pair fragment. 

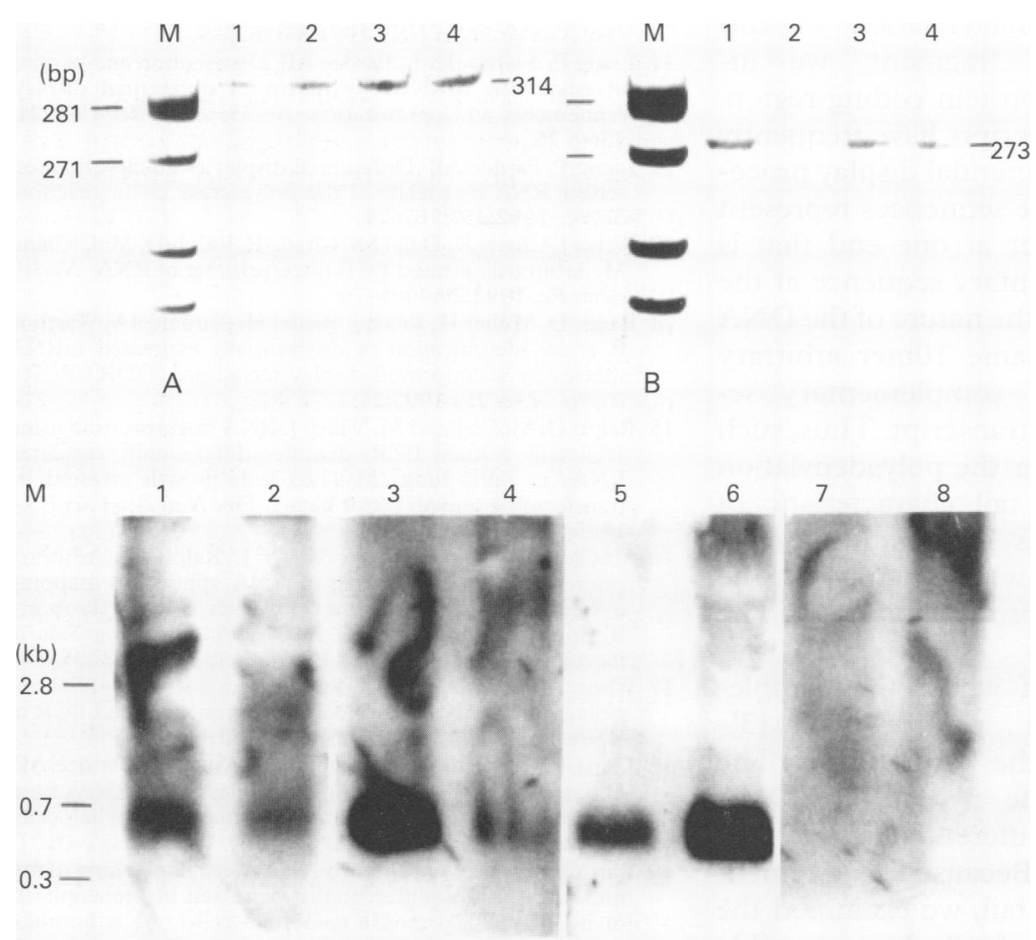

Figure 2 Electrophoretic pattern of DNA after amplification with sequence-specific primers by $R T-P C R$ in $5 \% P A A$ gel after silver staining. $(A) D N A$ fragment expressed in SCC cell lines corresponding to 314 base pairs produced from the 1 sense and 1 antisense primer combination (table 1). (B) DNA fragment generated in a second PCR corresponding to 273 base pairs from the 2 sense and 2 antisense nested primer combination (table 1). The cells used were: HCFMK-1 (lane 1), UM-SCC-14B (lane 2),

UM-SCC-17B (lane 3), and Hlac-78 (lane 4). M, molecular weight standards.

(C) Detection of the differentially expressed fragment by non-radioactive northern blot analysis using $20 \mu \mathrm{g}$ of total RNA per lane after agarose gel electrophoresis and transfer on to nitrocellulose. RNA was isolated from a moderately differentiated $S C C$ of the glottis, from a poorly keratinised SCC of the pyriform fossa, from the UM-SCC-17A, 14B, Hlac-78, and HCFMK-1 cell lines, as well as from laryngeal mucosal biopsies and from cultivated mucosal keratinocytes (lanes 1-8, respectively). Hybridisation was performed with random primed digoxigenin labelled probes specific for the 336 base pair fragment.

NESTED PCR AND NORTHERN HYBRIDISATION

To test the efficiency and specificity of the differentially expressed fragment, high stringency secondary RT-PCR using sequence specific sense and antisense primers was performed. Furthermore, the specificity of the amplification was enhanced with nested primers that annealed within the first primer pair. The differentially expressed fragment generated in the original DDRT-PCR could be amplified as a distinct fragment using both the first primer pair that produced a 314 base pair fragment and the nested PCR primers that produced a 273 base pair fragment, demonstrating the high specificity of the primers to the target sequence (fig 2A and B).

One-sided PCR was carried out to reconstruct the $3^{\prime}$ end of the mRNA. Using the 20mer forward SSP and the oligo(dT) primer, a 486 base pair PCR product was generated, encompassing the non-coding region with stop codons (TGA, TAA), polyadenylation signal (AATAAA) and the 3 ' end poly(A) tail (table 1). The total length of the fragment obtained was 694 base pairs (table 1). Following the forward primer the sequence contained the start codon (ATG) that codes for methionine. Further analysis of the sequence revealed no stop codon within the next 231 base pairs.
This 234 base pair long sequence may represent the coding region. The 3 ' end amplified part of the mRNA molecule was then compared again with the GenBank database and a homology of $52 \%$ with the gene sequence of the nematode worm Caenorhabdi- 궁 tis elegans was found, involving 198 base pairs of the 486 base pair PCR product.

Total RNA from SCC biopsies and cell lines was subjected to northern blot analysis using $\overrightarrow{\bar{N}}$ the differentially expressed 336 base pair $\overline{0}$ digoxygenin labelled probe (fig $2 \mathrm{C}$ ). Under the same hybridisation conditions, the probe hy- $\frac{\bar{s}}{T}$ bridised to an $\sim 0.7 \mathrm{~kb}$ mRNA from all tumour $\mathbb{\mathbb { }}$ biopsies and cell lines tested. The HCFMK-1, ڤ UM-SCC-14B, and UM-SCC-17A cell lines derived from poorly to well differentiated SCC of the floor of the mouth, as well as the $\vec{\omega}$ HlaC-78 cell line derived from a moderately to well differentiated SCC of the larynx, all exhibited a high expression rate. The hybridisa- if tion signal in the moderately differentiated is SCC biopsies from the glottis and in poorly keratinised SCC biopsies of the pyriform fossa 을 was weaker. No expression was detected in either mucosal biopsies, in mucosal keratino- $\frac{7}{0}$ cytes cultivated in vitro, in the three cancer cell lines, or in the pleomorphic adenoma of the parotid gland.

\section{Discussion}

Major technological advances in recombinant DNA, cloning, sequencing, and gene amplification methods have facilitated the use of RNA $\stackrel{\mathbb{Q}}{\mathcal{Q}}$ or cDNA probes in all areas of biomedical $\overrightarrow{\vec{A}}$ research. The differential display PCR tech- 윽 nique for gene amplification is a powerful tool and has been used in many aspects of molecular biology, in both research and diagnostic laboratories. The amplification of differentially expressed genes has been used successfully for vertebrates, ${ }^{29}$ and for eukaryotic organisms in general. ${ }^{1130-32}$

We applied the DDRT-PCR technique to analyse the gene expression profile of cultivated SCC cells and mucosal keratinocytes. Using a protocol for non-radioactive detection that we had recently modified, ${ }^{27}$ reproducible cDNA of fingerprints were achieved. Compared with $N$ differential cDNA library screening or subtractive hybridisation, the differential display technique has several distinct advantages. The pro- 0 cedure is fast, simple, and reproducible..$^{2933}$ It also has the potential to detect low abundance messages that cannot be detected with conventional hybridisation based approaches. ${ }^{11} 1433$

After reverse transcription of mRNA into $\frac{\Omega}{\mathbb{D}}$ cDNA with 3' two-based anchor primers and subsequent amplification with arbitrary primers, we detected a large number of transcripts $\frac{8}{0}$ and isolated a cDNA clone-containing sequence that reacted with all SCC samples, as confirmed by northern hybridisation.

Comparative analysis of the nucleotide sequence of the differentially expressed 336 base pair fragment did not reveal any significant homology with sequences in the DNA database. Furthermore, the sequence of the human $\mathrm{T}$ cell receptor $\beta$ locus showed the highest correspondence, with $63.0 \%$ overlap- 
ping within a small segment of only 54 base pairs. For further characterisation of this differentially expressed fragment, we attempted to identify the protein coding region. In practice, mRNA transcripts have frequently been detected by the differential display procedure, of which nucleotide sequences represent a $10 \mathrm{mer}$ arbitrary primer at one end that is matched by a complementary sequence at the other end. This is due to the nature of the DNA sequence-that is, the same $10 \mathrm{mer}$ arbitrary primer anneals to two complementary sequences within the same transcript. Thus, such sequences present neither the polyadenylation signal nor the poly(A) tail characteristic of mRNA molecules. This is, indeed, the case for the 336 base pair clone which starts with the 5'-TACAACGAGG-3' primer (table 1). The sequence ends with 10 bases (5'CCTCGTTGTA-3'), of which the complementary sequence is palindromic (3'GGAGCAACAT $-5^{\prime}$ ) to the 5' to 3' primer. The lack of added $A$ at the $3^{\prime}$ end of cDNA fragments detected by differential display is a well documented fact. ${ }^{14}$ Because this fragment was lacking the poly(A) tail, we examined the amino acid sequences of all three possible reading frames but did not find homologous sequences in the protein database. Additional 3' amplification was accomplished by onesided PCR. The result displayed the stop codons as well as the poly(A) signal of the mRNA. GenBank database comparison was repeated, but again revealed no identity with human gene sequences. This finding suggests that the fragment differentially expressed in laryngeal and floor of mouth carcinoma cells represents a novel gene. Additional analyses, including protein expression studies in bacterial expression systems, are in progress to obtain further information regarding the function of this selectively expressed transcript.

This study was supported by a grant from the Cancer Society of Schleswig-Holstein, Germany.

1 Bron L, Monnier P. Molecular alterations in head and neck squamous cell carcinoma. Clin Otolaryngol 1995;20:291-8.

2 Anwar K, Nakakuki K, Naiki H, Inuzuka M. ras gene mutations and HPV infection are common in human laryngeal tions and HPV infection are common

3 Rumsby G, Carter RL, Gusterson BA. Low incidence of ras oncogene activation in human squamous cell carcinomas. BrF Cancer 1990;61:365-8.

4 Somers KD, Cartwright SL, Schechter GL. Amplification of the int-2 gene in human head and neck squamous cell carcinomas. Oncogene 1990;5:915-20.

5 Lane DP. Cancer, p53, guardian of the genome. Nature 1992;358:15-16.

6 Hollstein M, Sidransky D, Vogelstein B, Harris CC. p53 mutations in human cancers. Science 1991;253:49-53.

7 Chung KY, Mukhopadhyay T, Kim J, Casson A, Ro JY, Goepfert $\mathrm{H}$, et al. Discordant p53 gene mutation in Goepfert $\mathrm{H}$, et al. Discordant p53 gene mutation in primary head and neck cancers and corresponding second primary cancers of the

8 St. John TP, Davis RW. Isolation of galactose-inducible DNA sequences from Saccharomyces cerevisiae by differential plaque filter hybridisation. Cell 1979;16:443-52

9 Zimmermann CR, Orr WC, Leclerc RF, Barnard EC, Timberlake WE. Molecular cloning and selection of genes regulated in Aspergillus development. Cell 1980;21:709 15 .
10 Lee SW, Tomasetto C, Sager R. Positive selection of candidate tumour-suppressor genes by subtractive hybridization. Proc Natl Acad Sci USA 1991;88:2825-9.

11 Liang P, Averboukh L, Pardee AB. Distribution and cloning of eukaryotic mRNAs by means of differential display: refinements and optimization. Nucleic Acids Res 1993;21: 3269-75.

12 Liang P, Pardee AB. Differential display of eukaryotic messenger RNA by means of the polymerase chain reaction. Science 1992;257:967-71.

13 Welsh J, Chada K, Dalal SS, Cheng R, Ralph D, McClelland $\mathrm{M}$. Arbitrarily primed PCR fingerprinting of RNA. Nucleic Acids Res 1992;20:4965-70

14 Bauer D, Müller H, Reich J, Riedel H, Ahrenkiel V, Warthoe $\mathrm{P}$, et al. Identification of differentially expressed mRNA species by an improved display technique (DDRT-PCR). Nucleic Acids Res 1993;21:4272-80.

15 Ralph D, McClelland M, Welsh J. RNA fingerprinting using arbitrarily primed PCR identifies differentially regulated RNAs in mink lung (MylLu) cells growth arrested by transforming growth factor beta 1. Proc Natl Acad Sci USA 1993;90:10710-14

16 McClelland $M$, Chada K, Welsh J, Ralph D. Arbitrary primed PCR fingerprinting of RNA applied to mapping differentially expressed genes. In: Pena, SD, Chakroborty $\mathrm{R}$, Epplen JT, Jeffereys AJ, eds. DNA fingerprinting: State of the science symposium. Basel: Birkhauser, 1993:103-15.

17 Wong KK, McClelland M. Stress-inducible gene of Salmonella typhimurium identified by arbitrarily primed PCR of RNA. Proc Natl Acad Sci USA 1994;91:639-43.

18 Liang P, Averboukh L, Keyomarsi K, Sager R, Pardee AB. Differential display and cloning of messenger RNAs from human breast cancer versus mammary epithelial cells. Cancer Res 1992;52:6966-8.

19 Sun Y, Hegamyer G, Colburn NH. Molecular cloning of five messenger RNAs differentially expressed in preneoplastic or neoplastic JB6 mouse epidermal cells: one is homologous to human tissue inhibitor of metalloproteinases- 3 . Cancer Res 1994;54:1139-44.

20 Carey T. Head and neck tumor cell lines. In: Hay RJ, Park JG, Gazdar A, eds. Atlas of human tumour cell lines. San Diego: Academic Press, 1994:79-119.

21 Zenner HP, Herrmann IF, Bremer W, Stahl-Mauge C. Head and neck carcinoma models. In vivo reproduction in athymic mice and in vitro culture. Acta Otolaryngol 1983;95:371-81

22 Goeroegh T, Lippert BM, Gottschlich S, Folz BJ, Werner JA. Etablierung und Charakterisierung zweier Zellinien von Plattenepithelkarzinomen des Mundbodens und der Zunge. Laryngorhinootologie 1995;74:684-90

23 Saffran S, Goeroegh T, Lippert BM, Werner JA. Kultivierung humaner Keratinozyten der Schleimhaut des oberen Aerodigestivtraktes. Laryngorhinootologic 1997;76: 101-5.

24 Russell WC, Newman C, Williamson DH. A simple technique for demonstration of DNA in cells infected with mycoplasma and viruses. Nature 1975;253:461-2.

25 Sambrook J, Fritsch EF, Maniatis T. Molecular cloning. a laboratory manual. 2nd edn. Cold Spring Harbor: Cold Spring Harbor Laboratory Press, 1989.

26 Bassam BJ, Caetano-Annoles G, Gresshoff PM. Fast and sensitive silver staining of DNA in polyacrylamide gels. Anal Biochem 1991;196:80-3.

27 Goeroegh T, Folz BJ, Gottschlich S, Lippert BM, Rudert $\mathrm{HH}$, Werner JA Non-radioactive detection of differentially expressed mRNAs in head and neck carcinoma cells. In Werner JA, Lippert BM, Rudert HH, eds. Head and neck cancer. Advances in basic research. Amsterdam: Elsevier, 1996:183-91

28 Ohara O, Dorit RL, Gilbert W. One sided polymerase chain reaction: the amplification of cDNA. Proc Natl Acad SCi USA 1989; 86:5673-7.

29 Adati N, Ito T, Koga C, Kito K, Sakaki Y, Shiokawa K. Differential display analysis of gene expression in developing embryos of Xenopus laevis. Biochem Biophys Acta 1995 1262:43-51.

30 Lohmann J, Schickle H, Bosch TCG. REN display, a rapid and efficient method for nonradioactive differential display and mRNA isolation. Biotechniques 1995;18:200-2.

31 Linskens MHK, Feng J, Andrews WH, Enlow BE, Shahin $\mathrm{M}$, Saati SM, et al. Cataloging altered gene expression in young and senescent cells using enhanced differential display. Nucleic Acids Res 1995;23:3244-51.

32 Guimaraes MJ, Lee F, Zlotnik A, McClanahan T. Differential display by PCR: novel findings and applications. Nucleic Acids Res 1995;25:1832-3.

33 Loh EY, Elliott JF, Cwirla S, Lanier LL, Davis MM. Polymerase chain reaction with single sided specificity: analysis of T cell receptor delta chain. Science 1989;243 217-20. 